\section{Motivaatiokin vaatii ohjaamista}

Salmela-Aro, Katariina (toim.) (2018). Motivaatio ja oppiminen.

PS-kustannus. 229 sivua.

PSYKOLOGIAN ja kasvatustieteen tutkijoiden artikkeleista koostetussa teoksessa tarkastellaan motivaation ja oppimisen välistä suhdetta koulun viitekehyksessä. Teos herättää pohtimaan kouluarjen käytänteitä ja antaa käytännön välineitä moninaisten oppijoiden motivaation ja oppimisen tukemiseen. Kirjan keskeinen sanoma on, että sekä motivaatio että oppiminen pohjautuvat pitkälti oppijoiden kiinnostuksen herättämiseen ja ylläpitämiseen sekä heille merkityksellisten oppimiskokemusten tavoittamiseen.

Yksi ydinkäsite on 'oppimismotivaatio', joka teoksen toimittajan Katariina Salmela-Aron mukaan on "toimijuutta, pystyvyyttä ja merkityksellisyyttä". Hän painottaa, että kyvyt luoda uutta arvoa maailmaan, ottaa vastuuta ja sovitella ovat tärkeitä, "jotta tulevaisuuden maailma voi pysyä tasapainossa ja selvitä vastoinkäymisistä. Nykyiset ja tulevaisuuden ongelmat ovat niin viheliäisiä, että niiden ratkaisemiseen tarvitaan yhteistyötä ja motivoituneita yhteisöjä.

TILANNESIDONNAISUUS JA SOSIAALINEN ULOTTUVUUS

Kirjassa lähdetään liikkeelle perinteisestä yksilökeskeisestä näkökulmasta motivaatioon: mikä oppijoita motivoi? Kysymystä tarkastellaan muun muassa oppijoiden kokeman kouluinnon ja uupumuksen, erilaisten ajattelu- ja tilanteiden tulkintatapojen sekä oppiaineiden arvostuksen näkökulmista.

Seuraavaksi katsetta lavennetaan oppimismotivaation tutkimuksen pohjalta ilmiön tilannesidonnaisuuteen ja sosiaaliseen ulottuvuuteen: miten motivaatio rakentuu ja rakennetaan yhteistyössä? Tarkastelu ulottuu lasten ja nuorten kaverisuhteista opettajan ja vanhempien rooliin.

Hyvin monet teoksen kirjoittajista painottavat koulumaailmassa tarvittavan henkilökunnan vahvaa ohjausosaamista ja dialogisuutta eli ohjauksellista työotetta, jonka Jussi Onnismaa tiivistää sanoihin "aikaa, huomiota ja kunnioitusta". Näin siksi, että kaikilla oppijoilla sisäinen motivaatio tai itseohjautuva oppiminen eivät synny itsestään esimerkiksi ilmiö- tai projektioppimisen myötä. Oppiminen pitää järjestää laadukkaasti, ja lisäksi tarvitaan opettajan tuki.

Erityisesti opettajalta vaaditaan joustavaa tilannekohtaista ohjausta ja oppimisympäristön säätelyä, kun oppilaat ovat motivaationaalisesti haavoittuvia. Teoksessa esitellään vuorovaikutuksen avulla oppimisen malli, Teaching Through Interaction. Se

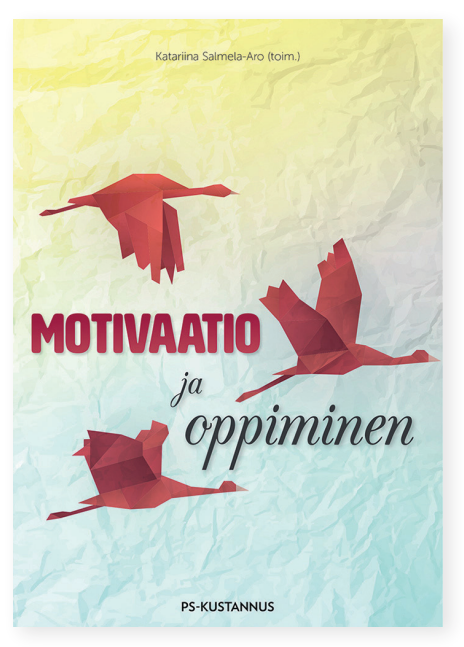

on osoittanut, että ryhmän ilmapiiri, laadukas ohjauksellinen tuki sekä toiminnan selkeä organisointi ovat yhteydessä hyviin oppimistuloksiin.

\section{MOTIVAATION YHTEISSÄÄTELYN KAKSISUUNTAISUUS}

Kouluissa tehdään paljon ryhmätöitä ja pitkäkestoisia, oppiainerajat ylittäviä projekteja, koska niiden ajatellaan kehittävän työelämätaitoja.

Motivaation ja oppimisen kannalta ilmiö- ja projektipohjaisuus tarkoittaa, että oppijoiden pitäisi pystyä ryhmänä ensinnäkin ymmärtämään, kun heidän oppimisprosessinsa on uhattuna. Toiseksi heidän olisi tunnistettava syyt, jotka oppimisprosessia uhkaavat tai haastavat. Kolmanneksi oppijoiden olisi kyettävä mukauttamaan toimintaansa oppimisen haasteiden ratkaisemiseksi.

Edellä kuvattu motivaation yhteissäätely vaatii taitojen har- 


\section{MotivaATION YHTEISSÄ̈̈TELY VAATII}

TAITOJEN HARJOITTELUA JA OPETTELUA. joittelua ja opettelua kouluissa, sillä muuten ryhmä ei pääse käyttämään koko oppimisen potentiaaliaan. Myös tässä yhteydessä on olennaista, että opettaja toimii motivaation kanssasäätelijänä, kun oppilaat opiskelevat ryhmissä.

Teoksessa tunnutaan painottavan aikuisten, eli henkilökunnan ja vanhempien vahvaa roolia, jopa vastuuta oppilaiden motivaation ja oppimisen prosesseista. 'Evokatiivisuuden' käsitteen tarkastelu tuo kuitenkin tähän näkökulmaan toisenlaista särmää ja korostaa lasten ja nuorten aktiivista toimijuutta oman ympäristönsä muovaajina. 'Evokatiivisella vaikutuksella' tarkoitetaankin sitä, että myös lasten ja nuorten ominaisuudet, kuten sosiaalinen tausta, temperamentti, taidot ja kiinnostus opiskeltavaan aineeseen, vaikuttavat siihen, kuinka heihin suhtaudutaan, millaisessa vuorovaikutuksessa heidän kanssa ollaan ja millaisia mahdollisuuksia heille tarjotaan.

Toisia oppijoita voi siis olla helpompi kannustaa ja motivoida, mikä on hyvin inhimillistä. Evokatiivisuuden merkityksen oppimisen ja motivaation yhteissäätelylle voikin teosta lainaten nähdä myös näin: "Näiden osin itseään ylläpitävien kehien tiedostaminen voikin auttaa vanhempaa [myös opettajaa] uudelleen suun- taamaan kehityskulkua silloin, kun lapsen tai nuoren oppimismotivaatio on heikko."

\section{MOTIVAATIO ON \\ ELINIKÄINEN PROSESSI}

Motivaatio ja oppiminen lupaa esitellä "oppimiseen vaikuttavia tekijöitä kiinnostavasti ja monipuolisesti”. Näin teos myös tekee, ja keskittyminen koulun viitekehykseen tekee kokoomateoksesta eheän. Johdannossa kuitenkin viitataan siihen, että motivaatio ja oppiminen on elinikäinen prosessi.

Olisikin mielenkiintoista lukea aikuisten motivaatiota ja oppimista tutkineiden ajatuksia siitä, kehittyykö opittavissa oleva oppimismotivaatio vain nuoruudessa vai tuleeko herkkyyskausia vastaan myöhemminkin elämässä. Entä millaista on motivaatio ja oppiminen esimerkiksi työn, perheen ja vapaa-ajan konteksteissa?

Kokonaisuudessaan teos esittelee keskeisiä motivaatioteorioita ja niitä valottavaa, tuoretta suomalaistutkimusta sopivan ytimekkäinä annoksina. Näin teos tarjoaa myös aikuiskasvatuksen näkökulmasta mielenkiintoisen peruslähdeteoksen ja ensikosketuksen aiheeseen, sillä se on helppolukuinen, tutkimustietoon perustuva johdatus oppimismotivaation ilmiöihin. Jokainen luku päättyy lähdeluetteloon, mikä mahdollistaa syventymisen aiheeseen.

Vankka tieto yhdistetään kiinnostavaan ja kriittiseenkin pohdintaan tiedon merkityksestä arjen käytännöissä. Salmela-Aro esimerkiksi muistuttaa, että kouluissa on opetusohjelman ylikuormitus. Siksi oppilailla ei ole aikaa oppia keskeisiä käsitteitä eikä elää tasapainoista elämää, johon kuuluvat koulun lisäksi ystävät, riittävä uni ja liikunta.

Teoksen takana on myös motivaatio- ja oppimispsykologian vahva, näkemyksellinen suomalainen edistäjä - ennen kirjan julkaisua menehtynyt professori Jari-Erik Nurmi. Teoksen kautta hänen perintönsä jää vahvana elämään.

\section{JOHANNA RANTANEN}

PST, dosentti, ohjausalan yliopistotutkija Opettajankoulutuslaitos Jyväskylän yliopisto 